\title{
THE IMPACT OF SERVICE QUALITY ON BUSINESS COMMITMENT IN CONTRACT MANUFACTURING SERVICES: AN EXPLORATORY STUDY OF F\&B INDUSTRY IN MALAYSIA
}

\author{
Zulkefli Abdul Rahim* \\ Universiti Teknologi MARA, Samarahan Campus \\ Boo-Ho Voon \\ Universiti Teknologi MARA, Samarahan Campus \\ Rasidah Mahdi \\ Universiti Teknologi MARA, Samarahan Campus
}

\begin{abstract}
Business environment is highly competitive for food \& beverage (F\&B) industry due to the low entry barrier. In order to improve their financial performances, $\mathrm{F} \& \mathrm{~B}$ manufacturers opt to offer contract manufacturing services (CMS). There is a formal relationship established between the service provider and the buyer. However, the impact of service quality on retaining the business relationship particularly has not been empirically investigated. To fill this gap, this study explores the determinants of contract manufacturing service quality (CMSQ) and the interrelationship between CMSQ, customer satisfaction and loyalty of the F\&B CMSs' customers in Malaysia. Four focus group interviews (28 participants) were held in this study and they comprised 12 contract manufacturers and 16 business customers. Three new dimensions were discovered from the focus group interviews; product development capability, Halal certification and outcome quality in addition to the SERVQUAL dimensions. Relevant information via structured questionnaires were collected via online survey and drop-off method. 146 usable questionnaires were analysed using partial least squares. The results indicate that CMSQ consists of eight dimensions namely empathy, assurance, reliability, responsiveness, tangibles, outcome quality, Halal certification and product development capability. The Empathy dimension is the most important dimension influencing customers' decision to stay with the contract manufacturers. CMSQ was found to have a small effect size on loyalty while customer satisfaction largely influenced loyalty. The result implies that CMSQ is a complement in the formation of customer loyalty while customer satisfaction is a significant predictor of behavioural intention. The findings also provide empirical evidence that the contextual specific service quality is essential particularly for contract manufacturing in F\&B.
\end{abstract}

Keywords: Contract manufacturing services; Contract manufacturing service quality; Service quality; Customer satisfaction; Loyalty; Food services industry

Received: 4 September 2018

Accepted: 16 March 2019

\footnotetext{
* Corresponding author: Zulkefli Abdul Rahim, Faculty of Business Management, Faculty of Business Management, Universiti Technology Mara, 94300 Kota Samarahan, Sarawak, Malaysia. Phone: +60198183472. Email: zulkefliabdulrahim@yahoo.com
} 


\section{INTRODUCTION}

Today, business environment is highly competitive for the food and beverage (F\&B) industry. Due to the low high-tech involvement, the industry is considered as having a low entry barrier and it draws a high number of players. In spite of endless demand from the customers, manufacturers are facing tremendous challenges to meet customers' expectations and to maintain their loyalty. The situation becomes more complicated when the channel members choose to distribute their own brand and the retailer offers its own store brands and private labels (Meza \& Sudhir, 2010). Such situation reflects the declining power of manufacturers when compared to retailers (Webster, 2000). There is an apparent competition between the channel members and the manufacturers to penetrate the market. In order to lessen the competition and to take advantage of the present scenario, manufacturers need to offer contract manufacturing services (CMS) from merely concentrating on building own brand. However, the move is not an easy task since the manufacturer needs different sets of management approaches (Edvardsson, Gustafsson, \& Roos, 2005). To succeed in dual offerings; services and tangible products, the firms are required to improve technologies and enhance people's competency for supporting system integration capabilities.

CMS has been well practiced for decades in developed countries mainly Europe, and the trends are increasingly accepted globally including Malaysia, especially among F\&B business enterprises. Malaysia has recorded a value share of $2 \%$, which is regarded as the highest among Southeast Asian countries (The Nielsen Company, 2014). Despite of ready market, contract manufacturers (CMs) should not take their customers lightly in servicing them. In contract manufacturing business model, the success of long-term business relationship portrayed between CMs and the customers lies within an efficient service delivery and superior market performance. To attain a highperformance service provider, $\mathrm{F} \& \mathrm{~B} \mathrm{CMs}$ need to respond to fast-changing market environment as well as strive to improve service quality. Consumers are concerned about quality, looking for healthier, safer and Halal products. The need of certification from independent party among the manufacturers are apparent to signify the products are conformed to the international standard. To gain competitive advantage, manufacturers have attempted to improve their service quality, which is reflected through multidimensional constructs as perceived by customers. Superior service quality has shown able to build and maintain a long-term customer relationship (Gounaris, 2005a), and it is regarded as a differentiation strategy to gain competitive edge in a highly competitive business environment.

There is a growing interest on service quality among the business-to-business (B2B) service contacts, due to the value creation through the relationship is enormous (Narayandas, 2005). However, studies of customers' decision with regard to service quality attributes in B2B markets are scarce (Gounaris, 2005a), hence studies of business customers decision to stay with the F\&B service providers are significantly needed (Tey, Brindal, Mohamed Arshad, Mohd Noh, Abdul Hadi \& Darham, 2014), particularly in the context of contract manufacturing services. Given the knowledge gap, this study aims to explore the impact of service quality on business commitment in contract manufacturing contextual particularly in F\&B industry. 


\section{RESEARCH LITERATURE}

\subsection{Buyer-Seller Relationships in Contract Manufacturing Services}

Contract manufacturing refers to a business model that the firms secured the manufacturing contracts to manufacture the goods for the outsourcing firms based on their own or the customers' designs, formulas, and/or specifications. The manufactured goods bear the label or buyer's brand (Hsiao \& Chen, 2013). In such business model, the buyer-seller's relationship is bonded through several forms of agreements. They are either in the form of formal contracts, trusting agreements, open communications, secretive, cooperation or totally independent of each other (Cannon \& Perreault, 2010). The formation of relationship is established when there is a congruent intention between the seller and the buyer (Grönroos \& Helle, 2012). Many studies had explored the insights into the nature of buyer-seller relationships (Cannon \& Perreault, 2010; Gounaris, 2005b; He, Huang, \& Wu, 2018; Leonidou, Aykol, Fotiadis, \& Christodoulides, 2017; Viio \& Grönroos, 2016), however, limited study focus on service quality attributes. Findings revealed that, effective bonding with the customers, lead to trust, and this in turn results in affective commitment to the provider that upholds the relationship.

\subsection{Service Quality}

Service quality is the key marketing strategy and is inseparable to the business enterprises in today's highly competitive business world, especially in order for them to gain customer satisfaction and their loyalty (Namin, 2017; Omar, Fadzil Ariffin, \& Ahmad, 2016). Continuous research on exploring service quality dimensions for all business settings and context is crucial as its identification enables the marketing scholar and practitioner to spell out, measure, manage and improve customer perceived service quality (Voon, 2017; James, Calderon, \& Cook, 2017; Pantouvakis \& Francesca, 2016).

Several studies had been carried out by the scholars on the determinants of service quality as well as the relationship between service quality and customer satisfaction as well as behavioral intentions in food service establishment (Alhelalat, Habiballah, \& Twaissi, 2017; Voon, 2017; Hanks, Line, Gon, \& Kim, 2017; Liu \& Lee, 2016; Murad \& Ali, 2015; Namin, 2017; Yulisetiarini, 2014). Most of the service quality dimensions presented by the researchers stemmed from the SERVQUAL model. However, the model was unable to capture service quality of a food manufacturing industry that offers contract manufacturing services, since it has dual core offerings; tangible products and services. Furthermore the core product of the industry affects the safety and health of the consumers and the beliefs (Demirci, Soon, \& Wallace, 2016; Haghiri, 2016; Mukhtar $\&$ Butt, 2012). In addition, several studies found out service quality is an industry-specific matter (Andaleeb \& Conway, 2006; Gounaris, 2005a), as such SERVQUAL model is unlikely able to capture service quality of a manufacturing industry. Hence, the exploring of other dimensions are necessary to explain the dimension of CMSQ.

\subsection{Customer Satisfaction}


Service marketing literature reported that when considering the satisfaction of B2B clients, it is necessary to evaluate the satisfaction of the different components of the buying centre that are in contact with the service providers (Chumpitaz \& Paparoidamis, 2004). Those inputs are valuable as they stemmed from the members who experienced through interactions with the service provider and individual experts. With regard to industrial market, customer satisfaction is an overall evaluation of the total purchase, use and relationship experience with a product or services over time, as expressed by members of the buying decision centre and how products and services supplied by a firm meet or surpass customer expectation (Caceres \& Paparoidamis, 2007).

\subsection{Loyalty}

In CMS relationship, customer loyalty is shown through deep commitment to the firm, despite any situational influences and marketing efforts that could lead to switching behaviour (Oliver, 1999). Customer loyalty is crucial in B2B contexts as it reflects through long-term relationship. In buyerseller relationships, loyal buyers are more likely to focus on long-term benefits and engage in cooperative actions which are beneficial to both partners than disloyal buyers, thus enhancing the competitiveness of both partners and reducing transaction costs (Cannon \& Perreault, 2010; Russo, Confente, Gligor, \& Autry, 2016; Wolter, Bock, Smith, \& Cronin, 2017).

\section{RESEARCH FRAMEWORK AND PROPOSITIONS}

The research framework for the study is shown in Figure 1 below. Service quality model was referred to Parasuraman, Zeithaml, \& Berry (1988), and it consists of five (5) dimensions, namely Tangibles, Reliability, Responsiveness, Empathy and Assurance. Product development capability, Outcome quality and Halal certification dimensions were developed from focus groups interview.

Tangibles refers to the appearance of physical facilities, equipment, personnel and communication tools possess as shown by the Contract Manufacturer (CM). Responsiveness refers to the willingness and the readiness of the $\mathrm{CM}$ to help customers and provide prompt service. Empathy refers to the amount of caring and individualized attention provided by the $\mathrm{CM}$ to the customers. Assurance refers to the knowledge and courtesy of the CMs' employees and their ability to inspire trust and confidence in customers. Product development capability refers to the capability and competency of the CM to develop a quality product that provides unique value to consumers as well as improve the existing ones (Hsiao \& Chen, 2013). Halal means permissible or lawful. State of free from contacts or contains swine and its by-products, alcohol, blood, certain types of animals, and all kind of meat which has not been slaughtered according to Islamic procedures and the state of cleanliness of the processing areas (Mukhtar \& Butt, 2012). Outcome quality refers to the outcome of the service performance (Grönroos, 1984).

Four propositions were established to resolve the research problems and objectives.

\section{P1: $\quad$ CMSQ dimensions identification}

P2: CMSQ dimensions positively influence customer satisfaction

P3: Customer satisfaction positively influence customer loyalty 
P4: CMSQ dimensions positively influence customer loyalty

Figure 1: Research Framework

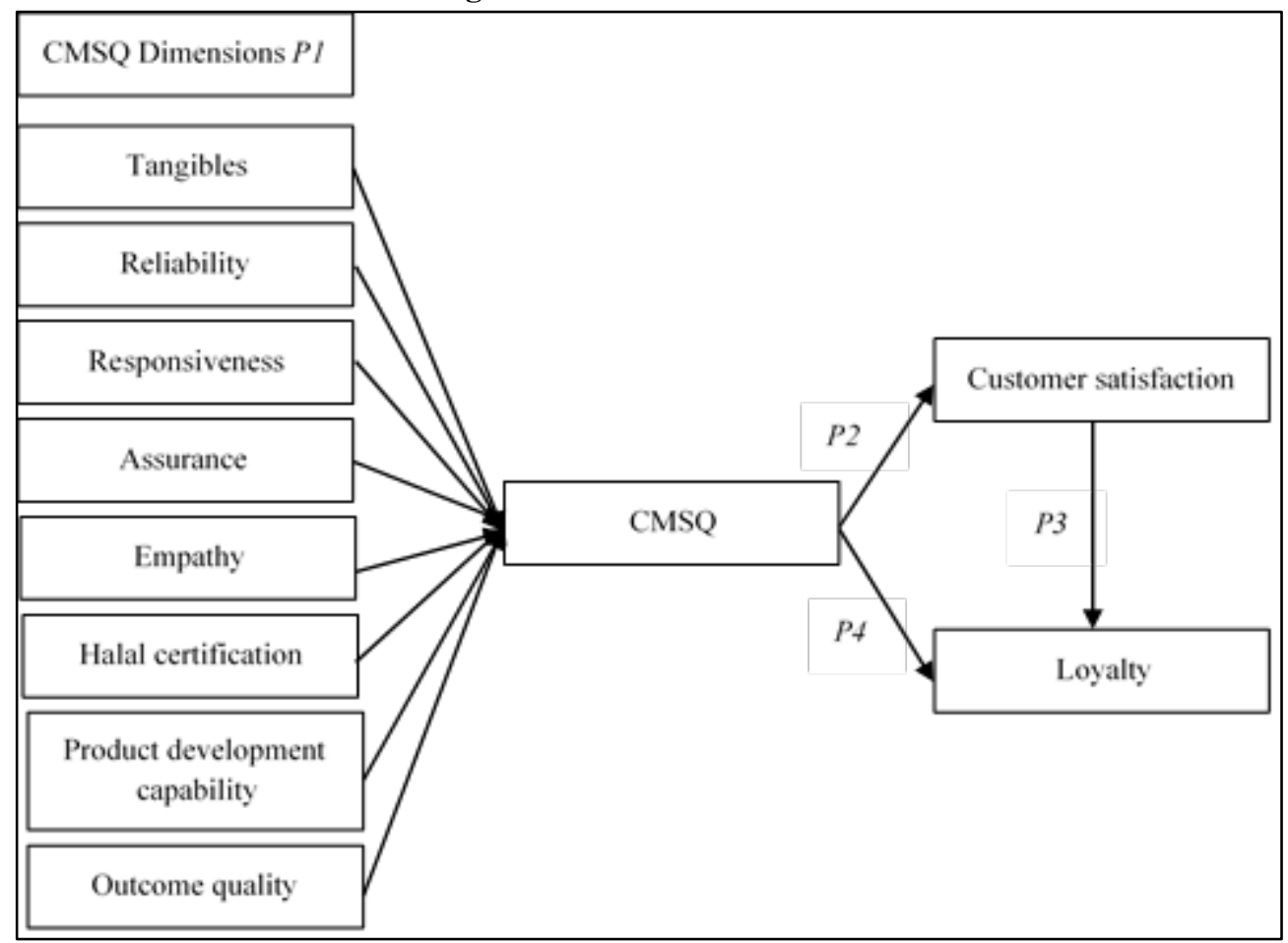

\section{METHODOLOGY}

This study attempts to determine the dimension of contract manufacturing service quality (CMSQ) as perceived by the business customers in the food services industry as well as to investigate the interrelationship between service quality, customer satisfaction and loyalty. The exploratory research consists of two phases; qualitative and quantitative (Brady \& Cronin, 2001). The study began by identifying the important dimensions of resellers decision to engage with the service providers, by undertaking a literature search to ascertain previous work in the field. The literature review provided the basis for retaining the five-SERVQUAL dimensions, namely tangibles, reliability, responsiveness, empathy, and assurance. Qualitative phase primarily involved focus group discussions with the aim to reconfirm the existing dimensions as well as to unearth the new dimensions and delineating the number of conceptual variables to be investigated. The items are to be incorporated into a Likert-type instrument and administering the instrument to a sample population consisting of contract manufacturers' customers. Quantitative phase, data was collected via self-administered questionnaires sent to the contract manufacturers' customers in order to test the hypothesized relationships. 


\subsection{Focus Group Discussions}

Four focus group interviews (28 participants) were held in this study using a semi-structured guide questions, and they were made up of 12 contract manufacturers and 16 business customers. The discussion was performed to extract the new items that are not found in the presence literature as well as to identify the dimensions of CMSQ in contract manufacturing business setting. The participants were the key personnel, representing organizations that are actively engaged in contract manufacturing activity. The CMs were also invited for the discussions, since their presence are important to share their experience in providing the service to the customers. Interviews were digitally recorded, transcribed and coded. To code the data, inductive categorization method was used, involves labelling recurring theme found in a passage of text (Arnould \& Thompson, 2005). Based on focus group discussions, three new dimensions were identified; Outcome quality, Halal and Product development capability in addition to SERVQUAL dimensions.

\subsection{Questionnaire Development}

The draft questionnaire contained 47 items related to eight dimensions of service quality attributes which inclusive of 14 new items as a result of focus group discussion; Tangibles - 5 items, Reliability - 6 items, Responsiveness - 4 items, Empathy - 8 items, Assurance - 5 items, Product development capability - 4 items, Halal certification - items and Outcome quality - 4 items. 6 items measure customer satisfaction and 5 items assess loyalty. Source of the items refer to Appendix A The items were presented as statements on the questionnaire, with the same rating scale used throughout. The items were measured on seven-point Likert-type scales that vary from 1=strongly disagree to $7=$ strongly agree. The draft questionnaire was referred to the experts and pre-tested to 10 informants representing five companies and each company represented by two representatives. The chosen companies were actively contracted-out their products under private label. The informants were asked to rate the level of difficulty in understanding of each question using a scale of 1 to 5 with ' 1 ' being "very difficult" and ' 5 ' being "easy".

Scores for each question were aggregated for further evaluation. Each question was inspected for the mean score, percentage distribution as well as the percentage of 'No idea'. A high mean score (a high percentage of ratings 4 and 5) would indicate the question is acceptable and easy to understand and the question is retained. A low mean scores of below 4 indicates the question need attention, to be rephrased or eliminated. Any score of 'No idea' would indicate the question were too difficult to understand or irrelevant in the context of CMS. All the questions were given high scores reflecting that the informants understood the questions well and allow for data collection and no nil score of 'No Idea' was reported.

\subsection{Data Collection}

Data were collected from the CM's customers of F\&B industries throughout Malaysia, who actively, contracted-out their products for at least a year. In order to reach a wide sample of 
respondents, a self-administered survey was considered to be the appropriate tool to collect data. The respondents are not required to reveal themselves anywhere in the survey to ensure their anonymity (Andaleeb \& Conway, 2006). This research adopts two methods of survey: online survey and drop-off method. The questionnaire is emailed to the identified respondents and upon completion of the survey, the questionnaire will be returned to the sender by clicking a send button. On the contrary, drop-off method involves the researcher or representative of the researcher to travel to the respondent's location and hand-delivering survey questionnaires to respondents (Steele, Bourke, Luloff, Liao, Theodori, \& Krannich, 2001). Once the survey is completed, it will be collected by the representative or the researcher.

A total of 1568 questionnaires was emailed to the identified companies throughout Malaysia. Two months duration were given for the respondents to return the completed questionnaire to the sender and an additional of one month was given upon request by the respondent. Respondents will be followed-up with a gentle reminder through email, if there is no sign of response after two weeks (Hsiao \& Chen, 2013). A total of 82 questionnaires was returned resulting in a response rate of 5.23 per cent and upon closed scrutiny only 78 questionnaires were usable for analysis and yielded a 4.97 per cent usable recovery rate.

For the case of drop-off method, three representatives were appointed by the researcher to distribute the questionnaires to the identified respondents. In order to ensure a high recovery rate, the completed questionnaires will be collected personally by the representatives upon visiting them. The survey was conducted for three months; July till September 2015. A total of 137 questionnaires was delivered to the potential respondents, however 71 questionnaires were gathered, given a recovery rate of 51.82 per cent. Upon close examination, only 68 questionnaires were usable for analysis, equivalent to 49.64 per cent.

\subsection{Data Analysis}

The cases (146) were then analysed using the SmartPLS statistical software version 3.0 for the statistical analysis. To determine the structural path significance, the bootstrapping procedure was employed by generating the $T$-statistics (Wong, 2013).

\section{FINDINGS}

\subsection{Qualitative Findings}

Based on focus group discussions, three new dimensions were identified; Outcome quality, Halal certification and product development capability in addition to SERVQUAL dimensions. It is revealed that, in contract manufacturing services, business customers judged quality of service provided by the CMs are not merely based on SERVQUAL model but also, they emphasized on the Outcome quality, issue of Halal as well as CM's Product development capability.

\subsubsection{Outcome Quality}


Issues related to outcome quality were the most debated during the discussion as expected. Being a businessperson, the final outcome is critical in CMS since it determined the success of the relationship. Outcome quality is translated into the reliability of CM to perform the promise dependably (Parasuraman, Berry \& Zeithaml, 1991). In this type of business setting, evaluation of final delivered service is straight forward. Customers are relating the service delivered with the promises given earlier. Participants showed their dissatisfaction once the supplier delivered the product which is not according to the promises given, such as delivery time, product quality, production capacity and capability of the manufacturer to deliver the product as per ordered. As such, it will affect the relationship with their customer and portray bad image to the company and to a certain extent will result in the loss of business opportunity. The participant also stressed the need for the CM to maintain the quality as per sample agreed. Failure will result the product cannot be sold, or it might affect consumer health once the product is consumed. The issues were decided to be categorized under the outcome quality in congruent with the description proposed by Gounaris (2005a); Grönroos (1984) and Parasuraman et al. (1991).

\subsubsection{Halal Certification}

Issue of Halal certification has been discussed in length and thorough among the participants throughout the four focus groups' discussions. It is agreed that Halal is the key factor in appointing the CMs, since most of their customers are Halal concerned particularly among the Malays. The participants highlighted the importance of having Halal certificate for the products and consequences for not having the certificates. However, consumers must be cautious about the authenticity of Halal certificate and its validity. In Malaysia, the only approved Halal certificate is the one issued by Department of Islamic Development Malaysia (JAKIM). For non-Muslim customers, Halal logo is the only sign to show product is Halal. The public need to be aware and cautious about the presence of fake Halal logo products in the market as pointed out by the participants. Another important aspect to emphasize is the validity of the certificate, since, it is issued for three years' validity. Elements of Halal were also discussed in the focus groups. Among them were cleanliness and hygiene as well as the background of the ownership and employees. One of the participants pointed out that the main reason for his company buying drinking water from a specific company is because of Halal certification. He further emphasized that such supplier used Halal certified water filter when processing the drinking water. Another participant who contracted-out confectionery has switched from the non-Halal certified manufacturer to a Halal certified manufacturer.

Cleanliness is the toughest part to comply as compared to other Halal standard such as ingredients and slaughtering since it covers the whole premise including restrooms. Segregation between the processing area, packing and store is demanded by the Halal authority to avoid the possibility of cross contamination. However, the background of Muslim ownership has received mixed reaction in complying Halal standard. Majority of the participants accepted that the manufacturer does not necessarily have a Muslim ownership, however the presence of Muslim employees is well received. It is noticed that participants who preferred a Muslim CM to be their service provider could link to the background of the customers, mainly the Muslim.

\subsubsection{Product Development Capability}


The manufacturer must be able to come-up with the right product sample as requested by the customer prior to business engagement. The participants gave mixed response when discussing on the dependability of product development services. There are participants who formulated the product themselves and pass it to the CM for production, and there are also participants who are highly dependent on manufacturer's product development services. The capability of the CMs to offer many products will lead them to be a preferred choice, especially when the buyers are highly dependent on specific CM as source of supplies. There is a need for CM to establish product development services department supported with qualified personnel in order to serve customers excellently. New product development through collaboration with customers is able to reduce the product failure rate and shorten the time to enter the market. Competency in product development capability is regarded as superior service quality for a $\mathrm{CM}$ in satisfying clients and this is able to establish long-term business relationship (Chang, Pan, \& Yu, 2008).

\subsubsection{SERVQUAL dimension}

SERVQUAL dimension was found to be the basis for the service quality attribute as demonstrated throughout the discussions. Few items were considered relevant to be included in the respective SERVQUAL dimension. With respect to Tangibles, the participants stressed that, the importance for the employees to portray cheerfulness and motivated when performing the task, since it has relationship with job satisfaction. Motivated employees are able to deliver quality service as expected, and this is especially crucial to food industry. In food manufacturing industry, it is vital for the manufacturers to comply to the food safety standards since the product is main for human consumption. Manufacturers should able to produce food safety certificate when asked by the customers.

In relation to Empathy dimension, two items were considered relevant: issue of prioritizing and accessibility. The participant insisted that special consideration should be given to them when they place the order, especially when they have committed with the clients. Another issue which could satisfy the customers with the relationship is the ability to access the manufacturers satisfactorily. Hence, the manufacturers should provide the means where they can be communicated easily. Only one item was considered as new item under Reliability dimension that need to be tested empirically, where the participants requested the CMs not to reveal their formulation as well as their status to others and the relationship should be kept confidentially.

\subsection{Quantitative Findings}

\subsubsection{Research Model}

The research model of the study is depicted in Figure 2. All eight dimensions pertaining to CMSQ (empathy, assurance, reliability, outcome quality, responsiveness, tangibles, Halal certification, and product development capability) were constructed as independent variables pointing directly towards customer satisfaction as dependent variable. Such specification allows prediction of personal interaction on satisfaction in a structural model. 
Figure 2: Research Model of The Study

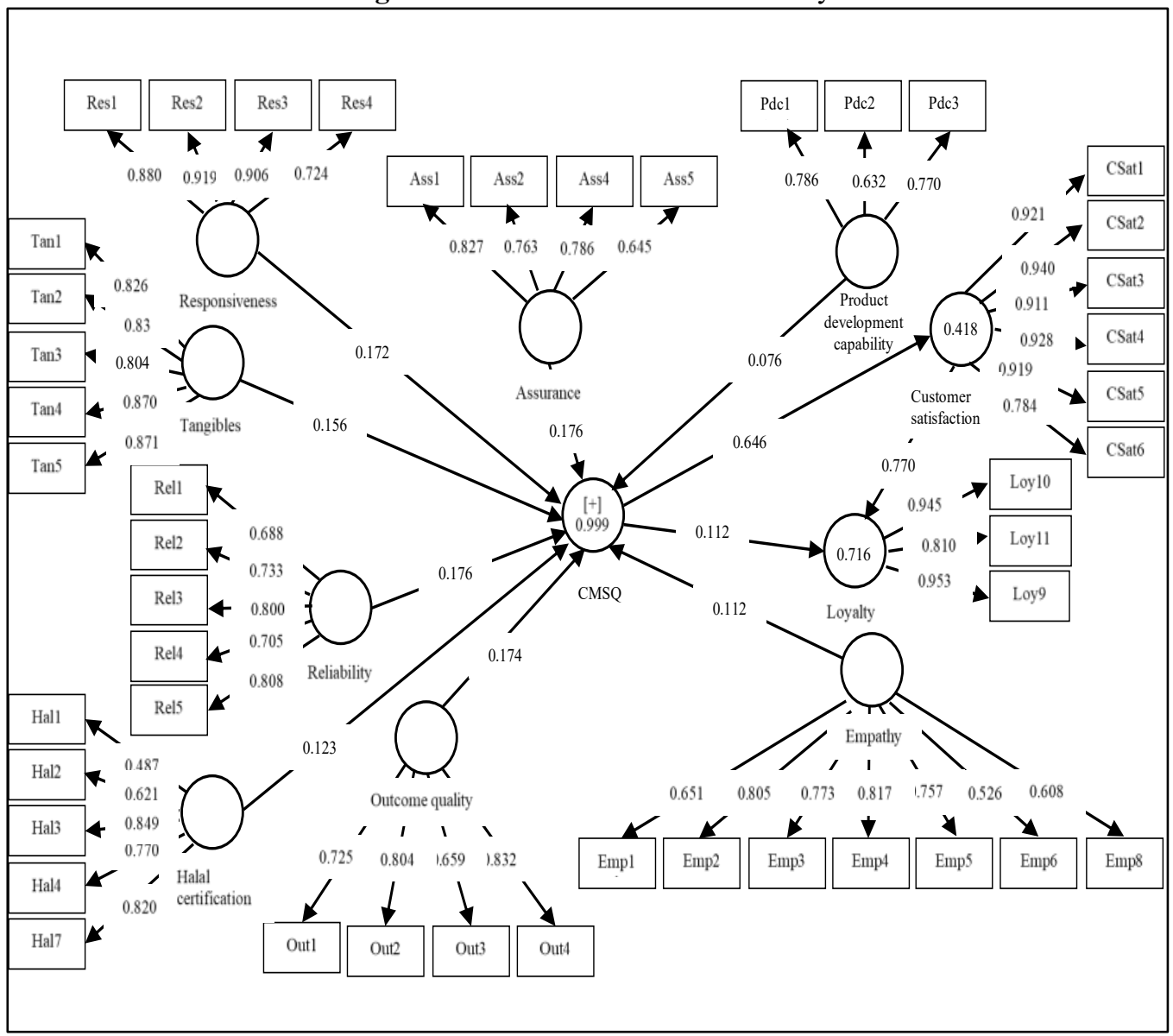

\subsubsection{Measurement Model}

In the first stage, measurement model was evaluated, to specify which measures are related to each latent variable construct, hence produce good measures for the construct. The latent constructs of "Tangibles" (Tan), "Reliability" (Rel), "Responsiveness" (Res), "Assurance" (Ass), "Empathy" (Emp), "Product development capability" (Pdc), "Outcome quality" (Out), "Halal certification" (Hal), "Customer satisfaction" (CSat) and "Loyalty" (Loy) were measured by their respective items.

\subsubsection{Individual item reliability}

The individual items reliability was assessed by looking at the outer factor loadings (Wong, 2013). This research adopted 0.5 as the threshold value for the scales (Field, 2005). Results of the initial analysis, shown that nine items were having low loadings $(<0.5)$, hence the items to be discarded. 
Even though item Pdc4 (We are highly dependent on our CM's product development service) was shown having loadings greater than 0.5 , the item needs to be discarded to improve measures for the product development capability constructs. The same goes to Halal certification construct, item Hal6 (Our CMs' processing equipment is Halal certified) needs to be discarded in order to improve measures for the Halal certification constructs. Subsequent run of the measurement model denotes that item Loy7 (We will recommend our CM to other customers when asked) is having lower loadings, hence it is to be discarded. In total, ten items of CMSQ constructs and two items from loyalty constructs were discarded.

The final results of the analysis are shown in Table 1. The loadings show that all the measurement items loaded higher on the latent variables; greater than 0.5 , which were proposed to measure the latent variables except for item Hall (Our CM possesses Halal certificate from the recognized authority) is retained, since it does not affect the measures as a whole. Furthermore, its existence is highly important to reflect the Halal certification constructs. The measurement items demonstrated a satisfactorily level of individual item reliability. Thus, thirty-seven items, grouped into eight dimensions, namely assurance, empathy, Halal certification, outcome quality, product development capability, reliability, responsiveness and tangibles, could be used to measure CMSQ of CMS.

Table 1: Results of the Final Run Measurement Model

\begin{tabular}{|c|c|c|c|c|c|}
\hline Constructs & $\begin{array}{c}\text { Measurement } \\
\text { items }\end{array}$ & Loadings & AVE & CR & $\begin{array}{c}\text { Convergent } \\
\text { validity }\end{array}$ \\
\hline \multirow{4}{*}{ Assurance } & B20 (Ass1) & 0.827 & 0.575 & 0.843 & Yes \\
\hline & B21 (Ass2) & 0.763 & & & \\
\hline & B23 (Ass4) & 0.786 & & & \\
\hline & B25 (Ass5) & 0.645 & & & \\
\hline \multirow{6}{*}{$\begin{array}{l}\text { Customer } \\
\text { satisfaction }\end{array}$} & C1 (CSat1) & 0.921 & 0.814 & 0.963 & Yes \\
\hline & $\mathrm{C} 2$ (CSat2) & 0.940 & & & \\
\hline & $\mathrm{C} 3$ (CSat3) & 0.911 & & & \\
\hline & $\mathrm{C} 4$ (CSat4) & 0.928 & & & \\
\hline & C5 (CSat5) & 0.919 & & & \\
\hline & C6 (CSat6) & 0.784 & & & \\
\hline \multirow{7}{*}{ Empathy } & B25 (Emp1) & 0.651 & 0.508 & 0.876 & Yes \\
\hline & B26 (Emp2) & 0.805 & & & \\
\hline & B27 (Emp3) & 0.773 & & & \\
\hline & B28 (Emp4) & 0.817 & & & \\
\hline & B29 (Emp5) & 0.757 & & & \\
\hline & B30 (Emp6) & 0.526 & & & \\
\hline & B47 (Emp8) & 0.608 & & & \\
\hline \multirow{5}{*}{ Halal certification } & B35 (Hall) & 0.487 & 0.522 & 0.840 & Yes \\
\hline & B36 (Hal2) & 0.621 & & & \\
\hline & B37 (Hal3) & 0.849 & & & \\
\hline & B38 (Hal4) & 0.770 & & & \\
\hline & B41 (Hal7) & 0.820 & & & \\
\hline \multirow{2}{*}{ Loyalty } & C10 (Loy10) & 0.945 & 0.819 & 0.931 & Yes \\
\hline & C11 (Loy11) & 0.810 & & & \\
\hline
\end{tabular}




\begin{tabular}{|c|c|c|c|c|c|}
\hline Constructs & $\begin{array}{c}\text { Measurement } \\
\text { items }\end{array}$ & Loadings & AVE & CR & $\begin{array}{c}\begin{array}{c}\text { Convergent } \\
\text { validity }\end{array} \\
\end{array}$ \\
\hline & C9 (Loy9) & 0.953 & & & \\
\hline \multirow{4}{*}{ Outcome quality } & B9 (Out1) & 0.725 & \multirow[t]{4}{*}{0.575} & \multirow[t]{4}{*}{0.843} & \multirow[t]{4}{*}{ Yes } \\
\hline & B13 (Out2) & 0.804 & & & \\
\hline & B14 (Out3) & 0.659 & & & \\
\hline & B15 (Out4) & 0.832 & & & \\
\hline \multirow{3}{*}{$\begin{array}{l}\text { Product } \\
\text { development } \\
\text { capability }\end{array}$} & B31 (Pdc1) & 0.786 & \multirow[t]{3}{*}{0.537} & \multirow[t]{3}{*}{0.775} & \multirow[t]{3}{*}{ Yes } \\
\hline & B32 (Pdc2) & 0.632 & & & \\
\hline & $\mathrm{B} 33(\mathrm{Pdc} 3)$ & 0.770 & & & \\
\hline \multirow{5}{*}{ Reliability } & B7 (Rel1) & 0.688 & \multirow[t]{5}{*}{0.560} & \multirow[t]{5}{*}{0.864} & \multirow[t]{5}{*}{ Yes } \\
\hline & B8 (Rel2) & 0.733 & & & \\
\hline & B10 (Rel3) & 0.800 & & & \\
\hline & B11 (Rel4) & 0.705 & & & \\
\hline & B12 (Rel5) & 0.808 & & & \\
\hline \multirow{4}{*}{ Responsiveness } & B16 (Res1) & 0.880 & \multirow[t]{4}{*}{0.741} & \multirow[t]{4}{*}{0.919} & \multirow[t]{4}{*}{ Yes } \\
\hline & B17 (Res2) & 0.919 & & & \\
\hline & B18 (Res3) & 0.906 & & & \\
\hline & B19 (Res4) & 0.724 & & & \\
\hline \multirow{5}{*}{ Tangibles } & B1 (Tan1) & 0.826 & \multirow[t]{5}{*}{0.709} & \multirow[t]{5}{*}{0.924} & \multirow[t]{5}{*}{ Yes } \\
\hline & B2 (Tan2) & 0.837 & & & \\
\hline & B3 (Tan3) & 0.804 & & & \\
\hline & B4 (Tan4) & 0.870 & & & \\
\hline & B5 (Tan5) & 0.871 & & & \\
\hline
\end{tabular}

\subsubsection{Internal Consistency}

Composite internal scale reliability was used to assess internal consistency construct instead of Cronbach's alpha, since the latter may over or underestimate the reliability coefficient, specifically when multidimensional measures or pre-specified sets of items are used (Hair, Sarstedt, Ringle, \& Mena, 2012. This research using 0.7 as a cut-off value of CR, all the latent variables demonstrated high levels of internal consistency among all ten latent variables, thus resulting an acceptable level of internal consistency (Table 1).

\subsubsection{Convergent Validity}

The average variance extracted (AVE) measures the variance captured by the indicators relative to measurement error, and the value should be greater than 0.50 to justify using the constructs (Hair, Sarstedt, Hopkins, \& Kuppelwieser, 2014). The results of AVEs are shown in Table 1, which provides support for convergent validity.

\subsubsection{Discriminant Validity}

Discriminant validity measures the extent to which the construct is empirically distinctive from other constructs (Hair et al., 2014). Fornell,Larker, \& Larcker (1981) criterion is used to assess the presence of discriminant validity. Table 2 displays the correlation matrix for the constructs. All the diagonal elements are greater than the off-diagonal elements in the corresponding rows and 
columns. Hence, the measurement model in this research demonstrates an adequate convergent and discriminant validity.

Table 2: Fornell-Lacker Criterion Analysis for Checking Discriminant Validity

\begin{tabular}{|c|c|c|c|c|c|c|c|c|c|c|}
\hline Constructs & Ass & CSat & Emp & Hal & Loy & Out & Pdc & Rel & Res & Tan \\
\hline Ass & 0.758 & & & & & & & & & \\
\hline CSat & 0.591 & 0.902 & & & & & & & & \\
\hline Emp & 0.617 & 0.571 & 0.713 & & & & & & & \\
\hline Hal & 0.440 & 0.370 & 0.429 & 0.722 & & & & & & \\
\hline Loy & 0.564 & 0.842 & 0.548 & 0.355 & 0.905 & & & & & \\
\hline Out & 0.717 & 0.629 & 0.595 & 0.413 & 0.564 & 0.758 & & & & \\
\hline Pdc & 0.418 & 0.366 & 0.518 & 0.393 & 0.385 & 0.406 & 0.733 & & & \\
\hline Rel & 0.691 & 0.491 & 0.567 & 0.363 & 0.466 & 0.713 & 0.366 & 0.749 & & \\
\hline Res & 0.677 & 0.442 & 0.708 & 0.445 & 0.385 & 0.644 & 0.444 & 0.630 & 0.861 & \\
\hline Tan & 0.379 & 0.297 & 0.414 & 0.399 & 0.287 & 0.328 & 0.342 & 0.409 & 0.373 & 0.842 \\
\hline
\end{tabular}

\subsubsection{Variation Inflation Factor}

VIF measures the degree of multicollinearity among the indicators for construct validation, as high multicollinearity could mean the indicator's information is redundant. Table 3 displayed the VIF for the reflective measurement models and the structural model. As shown in the table, VIF for all the indicators were all lower than 2.763 , indicates the low degree of redundancy of each measurement items (Hair et al., 2014). Therefore, multicollinearity is not an issue in this sample.

Table 3: Variance Inflation Factors

\begin{tabular}{llcc}
\hline \hline Constructs & $\begin{array}{l}\text { First Order VIF } \\
\text { CMSQ }\end{array}$ & Loyalty & $\begin{array}{c}\text { Structural model VIF } \\
\text { Customer Satisfaction }\end{array}$ \\
\hline Assurance & 2.763 & & \\
Empathy & 2.449 & & \\
Halal certification & 1.452 & & \\
Outcome quality & 2.723 & & \\
Product dev. capability & 1.474 & & \\
Reliability & 2.543 & & \\
Responsiveness & 2.672 & & \\
Tangibles & 1.378 & & \\
Loyalty & & 1.717 & \\
Customer Satisfaction & & 1.717 & \\
CMSQ & & & \\
\hline \hline
\end{tabular}


Based on the results obtained, the measurement constructs have shown good individual item reliability, internal consistency construct, convergent validity and discriminant validity. Therefore, based on the quantitative findings, CMSQ constructs which consist of eight dimensions as proposed, namely tangibles (5 items), reliability (5 items), responsiveness (4 items), assurance (4 items), empathy, product development capability (3 items), outcome quality (4 items) and Halal certification ( 5 items) met the criteria of measurement model. Measures for customer satisfaction and loyalty are 6 items and 3 items respectively. With all the values within the acceptable standard limits, and in addition the measurement items indicate low degree of redundancy, the measurement model in this research demonstrates sufficient robustness needed to test the relationship between the exogenous variable and the endogenous variables. Therefore, the proposed research model in this study refers to Figure 1.

\subsubsection{Structural Model}

In the second stage, the structural model was tested to seek the impact of CMSQ on customer satisfaction, customer satisfaction on loyalty and CMSQ on loyalty. In the structural model, path coefficients represent the standardized beta weights in regression analysis. A model is deemed fit when the r-square value is high, and t-values are statistically significant. To evaluate the statistical significance of path coefficients, a bootstrapping method was conducted. In this procedure, a bootstrap analysis with 500 subsamples was performed to give approximation $T$-values of the structural path for significance testing. A path coefficient is significant when its $2 \mathrm{t}$-tailed value is greater than 2.326 at 0.01 level; 1.96 at 0.05 level; 1.645 at 0.10 level. From the Table 4, all the three linkages are significant. CMSQ dimensions positively influenced customer satisfaction, $P 2$ (standardized path coefficient $=0.646, T$-Stat $=14.243, \mathrm{SE}=0.045$, and $\mathrm{p}<0.001$ ). Customer satisfaction positively influenced loyalty, $P 3$ (standardized path coefficient $=0.770, T$-Stat $=16.644, \mathrm{SE}=0.046$, and $\mathrm{p}<0.001$ ). CMSQ positively influence loyalty, $P 4$ (standardized path coefficient $=0.112, T$-Stat $=2.01, \mathrm{SE}=0.055$, and $\mathrm{p}<0.045$ ).

Table 4: T-Statistics of Path Coefficients

\begin{tabular}{lccccccc}
\hline \hline Propositions & $\begin{array}{c}\text { Original } \\
\text { Sample } \\
(\mathbf{O})\end{array}$ & $\begin{array}{c}\text { Sample } \\
\text { Mean } \\
(\mathbf{M})\end{array}$ & $\begin{array}{c}\text { Standard } \\
\text { Deviation } \\
(\mathbf{S T D E V})\end{array}$ & $\begin{array}{c}\text { T Statistics } \\
(|\mathbf{O} / \mathbf{S T D E V}|)\end{array}$ & $\begin{array}{c}\mathbf{P} \\
\text { Values }\end{array}$ & LLCI & ULCI \\
\hline $\begin{array}{l}\text { Ass -> } \\
\text { CMSQ }\end{array}$ & 0.176 & 0.177 & 0.016 & 11.051 & $0.000^{* *}$ & 0.126 & 0.179 \\
$\begin{array}{l}\text { CMSQ -> } \\
\text { CSat }\end{array}$ & 0.646 & 0.656 & 0.045 & 14.243 & $0.000^{* *}$ & 0.559 & 0.736 \\
CMSQ -> & 0.112 & 0.118 & 0.055 & 2.010 & $0.045^{*}$ & 0.038 & 0.270 \\
$\begin{array}{l}\text { Loy } \\
\text { CSat -> Loy }\end{array}$ & 0.770 & 0.765 & 0.046 & 16.644 & $0.000^{* *}$ & 0.677 & 0.861 \\
$\begin{array}{l}\text { Emp -> } \\
\text { CMSQ }\end{array}$ & 0.249 & 0.249 & 0.018 & 13.501 & $0.000^{* *}$ & 0.218 & 0.289 \\
$\begin{array}{l}\text { Hal -> } \\
\text { CMSQ }\end{array}$ & 0.123 & 0.121 & 0.019 & 6.439 & $0.000^{* *}$ & 0.086 & 0.159 \\
$\begin{array}{l}\text { Out -> } \\
\text { CMSQ }\end{array}$ & 0.174 & 0.174 & 0.015 & 11.976 & $0.000^{* *}$ & 0.149 & 0.203
\end{tabular}




\begin{tabular}{lccccccc}
\hline \hline Propositions & $\begin{array}{c}\text { Original } \\
\text { Sample } \\
(\mathbf{O})\end{array}$ & $\begin{array}{c}\text { Sample } \\
\text { Mean } \\
(\mathbf{M})\end{array}$ & $\begin{array}{c}\text { Standard } \\
\text { Deviation } \\
(\mathbf{S T D E V})\end{array}$ & $\begin{array}{c}\text { T Statistics } \\
(|\mathbf{O} / \mathbf{S T D E V}|)\end{array}$ & $\begin{array}{c}\text { P } \\
\text { Values }\end{array}$ & LLCI & ULCI \\
\hline $\begin{array}{l}\text { Pdc -> } \\
\text { CMSQ }\end{array}$ & 0.076 & 0.077 & 0.012 & 6.110 & $0.000^{* *}$ & 0.051 & 0.100 \\
$\begin{array}{l}\text { Rel -> CMSQ } \\
\text { Res -> }\end{array}$ & 0.176 & 0.173 & 0.017 & 10.395 & $0.000^{* *}$ & 0.163 & 0.228 \\
$\begin{array}{l}\text { CMSQ } \\
\text { Tan -> }\end{array}$ & 0.172 & 0.171 & 0.017 & 10.169 & $0.000^{* *}$ & 0.141 & 0.202 \\
CMSQ & 0.156 & 0.151 & 0.023 & 6.796 & $0.000^{* *}$ & 0.106 & 0.193 \\
\hline \hline
\end{tabular}

Based on scores of path coefficients, resellers based their evaluation of the perceived service quality on their assessment of eight corresponding dimensions: empathy, assurance, reliability, outcome quality, responsiveness, tangibles, Halal certification, and product development capability.

Table 5 shows the $R^{2}$ for each of the endogenous variables in the research model. The two latent variables (Customer Satisfaction and CMSQ) moderately explain $71.6 \%$ of the variance in Loyalty, while one latent variable (CMSQ) moderately explains $41.8 \%$ of the variance in Customer Satisfaction. Customer Satisfaction was shown to have a large effect size (1.217) on Loyalty whilst CMSQ was shown to have small to medium effect size on Loyalty $(0.026)$.

Stone-Geisser's $Q^{2}$ used to assess the predictive validity (or relevance) associated with each latent variable in the proposed model, and in SmartPLS this is obtained through Blindfolding procedure. The Stone-Geisser's $Q^{2}$ value is considerably above zero, which supports the model predictive relevance for the endogenous construct.

Table 5: Coefficient of Determination $\left(R^{2}\right)$, Effect Size $\left(f^{2}\right)$ and Predictive Relevance $\left(Q^{2}\right)$

\begin{tabular}{lllll}
\hline \hline Latent Variables & $R^{2}$ & $Q^{2}$ & $f^{2}$ & Effect Size \\
\hline Loyalty & 0.716 & 0.548 & & \\
Customer Satisfaction & 0.418 & 0.316 & 1.217 & Large \\
CMSQ & & & 0.026 & Small \\
\hline \hline
\end{tabular}

\section{DISCUSSION}

This study has introduced an extended service quality model, namely Contract Manufacturing Service Quality (CMSQ) for contract manufacturing business model, which was referred from SQ Model (Parasuraman et al., 1988). The study investigated the components of CMSQ, its relationship with customer satisfaction and loyalty as well as between customer satisfaction and loyalty. The new dimensions: outcome quality, Halal certification, and product development capability were introduced following the outcome from focus group discussions. This study also provided empirical evidence that all the eight dimensions (empathy, assurance, reliability, outcome quality, responsiveness, tangibles, Halal certification, and product development capability) are 
significant components of CMSQ. The findings denoted that; it is important to complement all the eight dimensions of CMSQ in order for the CMs to offer superior customer service to their clients. Satisfied clients will remain with the existing service providers and demonstrate their loyalty through retaining the business relationship and spreading positive words of mouth to others, thus leading to business prosperity. The following recommendations will be beneficial to the $\mathrm{CM}$ in enhancing customer service with the intention to build a stable and long-term business relationship.

Empathy is regarded as the most influential dimension in retaining the customers in contract manufacturing business model, hence the CMs should pay great attention to it. Customers will feel themselves being appreciated once CMs provide personal attention to them. In contract manufacturing, it is easy to establish the relationship, since the number of customers per service providers are usually few (Liu, Liu, \& Lin, 2008), hence CM should take the opportunity to retain the relationships. CM's staff should emphasize on sincere interest in solving customers' problems, prioritize and understand the customer's specific requirement in meeting their desires, and ensured that the service providers can be accessed satisfactorily through various means of communication.

In the context of contract manufacturing, assurance dimension plays an important role to attract the customers to engage and continue the business with the CMs. In B2B market, the service providers are known to be professional, and such professionalism is demonstrated through the employee's behaviour that helps create confidence to the buyers. Employees must be ensured they are experts in handling the task and knowledgeable enough to handle customer request. This will create confidence to the clients that they are dealing with the right CMs. On top of that, the staff must politely deal with the customers. Customers will feel annoyed once they are badly treated. CMs should ensure any transactions record should be error-free such as the invoices, delivery note and statement of accounts, and any mistakes should be notified promptly to the customers. In addition, possessive of food safety certificates, that certified by third party is crucial for the CMs in order to convince the customers, the products manufactured is safe for consumption.

The findings also demonstrated that, CMs should uphold trust in the relationship by fulfilling all the commitments and promises in the relationship, failure which will result the customers switch to other service providers. In delivering the tangibles products, CMs should uphold the agreed agreements which has entered earlier, such as the time, quality and quantity. Those are important elements to satisfy the customers as they have next customers to be satisfied. CMs should portray good image such as cleaned and hygienic employees and workplace to attract potential customers to engage the business with them. Good-looking physical appearance is important to retain customers once inside (Barber \& Scarcelli, 2010). Modern-look equipment will reflect the capacity as well the capability of the manufacturers to deliver quality service. It is important to note the influence of responsiveness include of prompt action on customers' request and updating the customers when the service will be performed as well as the progress of the service

Food manufacturers should be aware of the importance of Halal compliance in their daily business operations. The findings highlighted that business customers are more likely to be confident with the Halal status of the premise. The operator should obtain authentic Halal certification from the approved Islamic bodies to build confidence among the customers. Finally, manufacturers that can offer product development services is regarded as providing superior service quality. Customers may find their cost lower to penetrate the market, hence able to offer competitive price or they may 
earn better margin. Moreover, the service helps the customers to speed-up the process of penetrating the products into the market.

The empirical results of this study provide an evidence that there is a significant relationship between CMSQ and loyalty, however the impact is small. In F\&B CMS, where the core offering is tangible (manufactured products), customers may base their assessments of service provider on both the tangible products and customer service (Parasuraman, 1998). Due to that, the relative role of service quality on customer evaluation of CMs may be lower as compared to when the core is intangible. Logically when the core cannot be readily seen, customers may base their evaluations of service providers primarily on cues associated with core offering, in this case service quality. This indicates that CMSQ is seen as a complement in the formation of loyalty in F\&B CMS. To business customers, product quality is extremely important and they frequently appoint their CM based on quality excellence (Chumpitaz \& Paparoidamis, 2004). In today's competitive business environment, product quality is the main criterion for the existence of business relationship.

\section{CONCLUSIONS}

The main contribution of this study is the identification and ranking of dimensions of resellers decision to stay with the existing $\mathrm{CMs}$ in F\&B industry. In connection to this, the study has proposed a service quality model for contract manufacturing services, namely Contract Manufacturing Service Quality (CMSQ). The dimensions are crucial for CMs to direct the assessment in the preferred direction in order to maintain the long-term business relationship with the customers. The research further contributes to the body of knowledge by developing a new 37 item instrument to capture the resellers decision dimensions on CMs, namely empathy, assurance, reliability, outcome quality, responsiveness, tangibles, Halal certification, and product development capability. The Empathy appeared to be the most influential dimension among the eight dimensions of CMSQ in building the business relationship in F\&B CMSQ context. The results strongly revealed that, empathy is the component of relationship marketing and it is vital in attracting and maintaining the relationship.

The findings from the study also revealed that CMSQ was found to have a large impact size on customer satisfaction, and the impact size on loyalty was reported as small. The eight constructs of CMSQ explained well customer satisfaction, hence providing a significant role of CMSQ dimension as an antecedent of customer satisfaction in this business setting. Even though the impact of CMSQ on loyalty is small, the service providers should not underestimate the importance of CMSQ dimension since it could jeopardize the business relationship once it is not being emphasized. In conclusion, for better generalization of F\&B industry, this study can be extended further by involving health care products in Malaysia. It is also suggested that further study to investigate the effect of moderating factors such as Halal in the relationship.

\section{REFERENCES}

Alhelalat, J. A., Habiballah, A., \& Twaissi, N. M. (2017). The impact of personal and functional aspects of restaurant employee service behaviour on customer satisfaction. International 
Journal of Hospitality Management, 66, 46-53.

Andaleeb, S. S., \& Conway, C. (2006). Customer satisfaction in the restaurant industry: An examination of the transaction-specific model. Journal of Services Marketing, 20(1), 311. doi: $10.1108 / 08876040610646536$

Arnould, E. J., \& Thompson, C. J. (2005). Reflections twenty years of research culture, consumer cct, theory. Journal of Consumer Research, 31(March), 868-882.

Barber, N., \& Scarcelli, J. M. (2010). Enhancing the assessment of tangible service quality through the creation of a cleanliness measurement scale. Managing Service Quality, 20(1), 70-88. doi: 10.1108/09604521011011630

Brady, M. K., \& Cronin, J. J. (2001). Some new thoughts on conceptualizing perceived service quality: A hierarchical approach. The Journal of Marketing, 65(3), 34-49.

Caceres, R. C., \& Paparoidamis, N. G. (2007). Service quality, relationship satisfaction, trust, commitment and business-to-business loyalty. European Journal of Marketing, 41(7/8), 836-867. doi: 10.1108/03090560710752429

Cannon, J. P., \& Perreault, W. D. (2010). Buyer-seller relationships in markets business. Journal of Marketing Research, 36(4), 439-460.

Chang, S. C., Pan, L. Y., \& Yu, H. C. (2008). The competitive advantages of Quanta Computer The world's leading notebook PC manufacturer in Taiwan. Total Quality Management \& Business Excellence, 19(9), 939-948. doi: 10.1080/14783360802224602

Chumpitaz, R., \& Paparoidamis, N. G. (2004). Service quality and marketing performance in business-to-business markets: Exploring the mediating role of client satisfaction. Managing Service Quality, 14(2/3), 235-248. doi: 10.1108/09604520410528653

Demirci, M. N., Soon, J. M., \& Wallace, C. A. (2016). Positioning food safety in Halal assurance. Food Control, 70, 257-270.

Edvardsson, B., Gustafsson, A., \& Roos, I. (2005). Service portraits in service research: a critical review. International Journal of Service Industry Management, 16(1), 107-121. doi: 10.1108/09564230510587177

Field, A. P. (2005). Quality control: Principles, practice and administration. New York: McGrawHill.

Fornell, C., Larker, D. F., \& Larcker, D. F. (1981). Evaluating structural equation models with unobservable variables and measurement error: Algebra and statistics. Journal of Marketing Research, 18(3), 382-388. doi: 10.2307/3150980

Gounaris, S. P. (2005a). Measuring service quality in b2b services: An evaluation of the SERVQUAL scale vis-a-vis the INDSERV scale. Journal of Services Marketing, 19(6), 421-435. doi: 10.1108/08876040510620193

Gounaris, S. P. (2005b). Trust and commitment influences on customer retention: insights from business-to-business services. Journal of Business Research, 58(2), 126-140. doi: 10.1016/S0148-2963(03)00122-X

Grönroos, C. (1984). A service quality model and its marketing implications. European Journal of Marketing, 18(4), 36-44. doi: 10.1108/EUM0000000004784

Grönroos, C., \& Helle, P. (2012). Return on relationships: Conceptual understanding and measurement of mutual gains from relational business engagements. Journal of Business \& Industrial Marketing, 27(5), 344-359. doi: 10.1108/08858621211236025

Haghiri, M. (2016). Consumer choice between food safety and food quality: The case of farmraised Atlantic salmon. Foods, 5(22), 1-11. doi: 10.3390/foods5020022 
Hair, J. F., Sarstedt, M., Hopkins, L., \& G. Kuppelwieser, V. (2014). Partial least squares structural equation modeling (PLS-SEM): An emerging tool for business research. European Business Review, 26(2), 106-121. doi: 10.1108/EBR-10-2013-0128

Hair, J. F., Sarstedt, M., Ringle, C. M., \& Mena, J. A. (2012). An assessment of the use of partial least squares structural equation modeling in marketing research. Journal of the Academy of Marketing Science, 40(3), 414-433. doi: 10.1007/s11747-011-0261-6

Hanks, L., Line, N., Gon, W., \& Kim, W. (2017). The impact of the social servicescape , density , and restaurant type on perceptions of interpersonal service quality. International Journal of Hospitality Management, 61, 35-44.

He, J., Huang, H., \& Wu, W. (2018). Influence of inter firm brand values congruence on relationship qualities in B2B contexts, 72(March), 161-173.

Hsiao, Y., \& Chen, C. (2013). Branding vs contract manufacturing: Capability, strategy, and performance. Journal of Business \& Industrial Marketing, 28(4), 317-334. doi: $10.1108 / 08858621311313910$

James, T. L., Calderon, E. D. V., \& Cook, D. F. (2017). Exploring patient perceptions of healthcare service quality through analysis of unstructured feedback, 71, 479-492.

Leonidou, L. C., Aykol, B., Fotiadis, T. A., \& Christodoulides, P. (2017). Betrayal in international buyer-seller relationships: Its drivers and performance implications. Journal of World Business, 52(1), 28-44.

Liu, C. S., \& Lee, T. (2016). Service quality and price perception of service : Influence on wordof-mouth and revisit intention. Journal of Air Transport Management, 52, 42-54.

Liu, F. H., Liu, H. Y., \& Lin, T. (2008). The competence and constraints of brand building for contract. Brand Management, 15(6), 412-432. doi: 10.1057/bm.2008.8

Meza, S., \& Sudhir, K. (2010). Do private labels increase retailer bargaining power ? Quant Mark Econ, 8, 333-363. doi: 10.1007/s11129-010-9085-9

Mukhtar, A., \& Butt, M. M. (2012). Intention to choose halal products : The role of religiosity. Journal of Islamic Marketing, 3(2), 108-120. doi: 10.1108/17590831211232519

Murad, S., \& Ali, M. (2015). An empirical study on brand image and customers ' willingness to pay a price premium for packaged food. Journal of Business and Management Review, 5(1), 111-126.

Namin, A. (2017). Revisiting customers' perception of service quality in fast food restaurants. Journal of Retailing and Consumer Services, 34(June), 70-81.

Narayandas, D. (2005). Building loyalty in business markets. Harvard Business Review, 1-9.

Oliver, R. L. (1999). Whence consumer loyalty? Journal of Marketing, 63, 33-44. doi: $10.2307 / 1252099$

Omar, M. S., Fadzil, H., \& Ahmad, R. (2016). Service quality, customers ' satisfaction and the moderating effects of gender: A study of Arabic restaurants. Procedia - Social and Behavioral Sciences, 224, 384-392.

Pantouvakis, A., \& Francesca, M. (2016). Exploring different nationality perceptions of airport service quality. Journal of Air Transport Management, 52, 90-98.

Parasuraman, A. (1998). Customer service in business-to-business markets: An agenda for research. Journal of Business \& Industrial Marketing, 13(4/5), 309-321. doi: 10.1108/08858629810226636

Parasuraman, A., Berry, L. L., \& Zeithaml, V. A. (1991). Refinement and reassessment of the SERVQUAL scale. Journal of Retailing, 67(4), 420. doi: 10.1111/j.1438- 
8677.2010.00335.x

Parasuraman, A., Zeithaml, V. A., \& Berry, L. L. (1988). Servqual : A multiple-item scale for measuring consumer perceptions of service quality. Journal of Retailing, 64(1), 12-40.

Russo, I., Confente, I., Gligor, D. M., \& Autry, C. W. (2016). To be or not to be ( loyal ): Is there a recipe for customer loyalty in the B2B context? Journal of Business Research, 69(2), 888-896.

Steele, J., Bourke, L., Luloff, A. E., Liao, P. S., Theodori, G. L., \& Krannich, R. S. (2001). The drop-off/pick-up method for household survey research. Journal of Community Development Society, 32(2), 238-250. doi: 10.1080/15575330109489680

Tey, Y. S., Brindal, M., Mohamed Ariffin, F., Mohd Noh, K., Abdul Hadi, I. H. A., \& Darham, S., (2014). The impact of service quality on business commitment in B2B segment of agribusiness : An exploratory study of HORECA sector in Malaysia. International Food Research Journal, 21(3), 883-889.

The Nielsen Company. (2014). The state of private label around the world. Retrieved from http://www.nielsen.com/us/en/insights/reports/2014/the-state-of-private-label-aroundthe-world.html

Viio, P., \& Grönroos, C. (2016). Industrial marketing management how buyer - Seller relationship orientation affects adaptation of sales processes to the buying process. Industrial Marketing Management, 52, 37-46.

Voon; B. H. (2017). Service environment of restaurants: Findings from the youth customers. Journal of ASIAN Behavioural Studies, 2(2), 67.

Webster, F. E. (2000). Understanding the relationships among brands, consumers, and resellers. Journal of the Academy of Marketing Science, 28(1), 17-23. doi: $10.1177 / 0092070300281002$

Wolter, J. S., Bock, D., Smith, J. S., \& Cronin, J. J. (2017). Creating ultimate customer loyalty through loyalty conviction and customer-company identification. Journal of Retailing, 93(4), 458-476.

Wong, K. K. (2013). Partial Least Squares Structural Equation Modeling ( PLS-SEM ) techniques using SmartPLS. Marketing Bulletin, 1-32.

Yulisetiarini, D. (2014). The relationship between service quality, customer satisfaction and loyalty in restaurant business in East Java. International Journal of Business and Management Invention, 3(5), 1-10. 